intake to patients with diverticular disorder would add much weight to the theory that the cause of the disease is dietary.

Spriggs et al. (1951), Connell (1961), Arfwidsson (1964), Wangel and Deller (1965), Misiewicz, Connell, and Pontes (1966), Parks and Connell (1969), Texter and Hightower (1970), and Parks (1970) found that activity in control subjects in the sigmoid, rectosigmoid, and rectum was increased by eating, but to a less extent than in diverticular disease (Arfwidsson, 1964; Parks and Connell, 1969; Parks, 1970).

The pressure studies recorded here confirm these findings and show that after a six-month course of methylcellulose rectosigmoid activity does fall and to the same range as rectal activity, which remains unchanged. Parks (1970) noted that rectal activity increased after excision of the sigmoid for diverticular disease and suggested that this operative treatment threw an added load on the continence mechanism of the rectum, with a great increase in fast-wave activity. Medical treatment with methylcellulose has not had this disadvantage.

Methylcellulose tablets, which expand to 25 times their original size after ingestion and were more acceptable to the patients than granules, were used to ensure that the patients under investigation received the necessary high residue. In addition to the pressure changes discussed all patients became asymptomatic. The improved sigmoidoscopic appearance could only be interpreted as evidence that methylcellulose overcame constipation without damaging the myenteric plexus by helping in the formation of large firm stools which could be passed easily per rectum without straining. It was therefore safe to maintain patients on methylcellulose as these patients with diverticular disease have a persistent tendency to eat low-residue foods.

This work suggests that the muscular abnormality of diverticular disease (Morson, 1963; Williams, 1965; Hughes, 1969) is acquired (Painter, 1969) and is reversible.
This work was carried out on a Charing Cross Governors' Clinical Research Fellowship and is part of the work for my M.S. thesis (London University). I wish to thank Professor Harding Rains for referring patients for this study and Mrs. J. Pheasant and Miss K. Marsh for their help in pressure recordings and wave measurement.

\section{References}

Adler, H. F., Atkinson, A. J., and Ivy, A. C. (1941). American fournal of Digestive Diseases, 8, 197.

Arfwidsson, S. (1964). Acta Chirurgica Scandinavica, Suppl. No. 342

Arfwidsson, S. (1964). Acta Chirurgica
Burkitt, D. P. (1969). Lancet, 2, 1229 .

Burkitt, D. P. (1969). Lancet, 2, 1229.

Chaudhury, N. A., and Truelove, S. C. (1961a). Gastrcenterology, 40, 1. (1961b). American fournal of Medicine, $31,86$.

Clayton Jones, E. (1956). Medical Press, 235, 551.

Connell, A. M. (1961). Gut, 2, 175.

Davidson, M., Sleisenger, M. H., Almy, T. P., and Levine, S. Z. (1956). fournal of Pediatrics, $17,807$.

Hodgson, J. (1972). British fournal of Surgery, 59, 315.

Holdstock, D. J., and Misiewicz, J. J. (1970). Gut, 11, 100.

Hughes, L. E. (1969). Gut, 10, 336.

Machle, W., Heyroth, F. F., and Witherup, S. (1944). fournal of Biological Chemistry, 153, 551

Misiewicz, J. J., Connell, A. M., and Pontes, F. A. (1966). Gut, 7, 468.

Morson, B. C. (1963). British fournal of Radiology, 36, 385

Painter, N. S. (1962). M.S. thesis London University.

Painter, N. S. (1962). M.S. thesis Lo

Painter, N. S. (1969). Lancet, 2, 586.

Painter, N. S., and Truelove, S. C. (1964). Gut, 5, 201, 365.

Painter, N. S., Almeida, A. Z., and Colebourne, K. W. (1972). British Medical Yournal, 2, 137

Parks, T. G. (1970). Gut, 11, 121

Parks, T. G., and Connell, A. M. (1969). Gut, 10, 534.

Ritchie, J. A., Ardran, G. M., and Truelove, S. C. (1962). Gastroenterology, 43, 642 .

Spriggs, E. A., Code, C. F., Bargen, J. A., Curtiss, R. K., and Hightower, N. C. (1951). Gastroenterology, 19, 480

Texter, E. C., jun., and Hightower, N. C., jun. (1970). Rendiconti Istituto Superiore di Sanita, 2, 47.

Wangel, A. G, and Deller, D. J. (1965), Gastroenterology, 48, 69.

Williams, I. (1965). British fournal of Radiology, 38, 437.

\title{
Relation between Serum Cholesterol and Triglyceride Concentration and Haemoglobin Values in Non-anaemic Healthy Persons
}

\author{
L. E. BÖTTIGER, L. A. CARLSON
}

British Medical fournal, 1972, 3, 731-733

\section{Introduction}

\section{Summary}

In a study of 2,458 healthy non-anaemic subjects a positive correlation was found between haemoglobin levels and serum cholesterol and triglyceride levels. This may be due to simple changes in plasma volume, which may increase when the haemoglobin concentration decreases. Such an association between plasma lipid levels and haemoglobin values might be of importance in the aetiology of coronary heart disease, as a high haemoglobin value is known to be a "risk factor" in myocardial infarction.

\footnotetext{
Department of Internal Medicine, Karolinska Hospital, Stockholm, Sweden

L. E. BÖTTIGER, M.D., Professor of Medicine

Department of Geriatrics, Uppsala University, Uppsala, Sweden L. A. CARLSON, M.D., Professor and Head of Department
}

Although Erben in 1902 reported low cholesterol levels in chlorosis, the possible relation between anaemia and hypolipidaemia did not attract much attention until the late 1960 s, when Rifkind and Gale (1967) reported on a small study of anaemic patients who also had low serum cholesterol and phospholipid levels. Ultracentrifuge analysis showed a proportionate decrease of cholesterol and phospholipids in all three main plasma lipoprotein fractions. Elwood et al. (1970), in a community-based study, found a statistically significant association between serum cholesterol and haemoglobin level. They found a mean difference of about $30 \mathrm{mg}$ of cholesterol per $100 \mathrm{ml}$ of blood between women with haemoglobin levels above and below 10.5 $\mathrm{g} / 100 \mathrm{ml}$.

Studies on the possible association between haemoglobin and serum cholesterol and haemoglobin and serum triglycerides in non-anaemic subjects have not been done previously. We have analysed fasting serum lipids (cholesterol and triglycerides) in about 6,500 persons in whom haemoglobin and erythrocyte sedimentation rate were also determined and have found a positive correlation between haemoglobin concentration and the two plasma lipids in both women and men, throughout the whole range of normal haemoglobin values. 


\section{Subjects and Methods}

The series of subjects was collected during 1961-2 at a health survey centre (Företagens Hälsokontroll, Stockholm) to serve as the basis of a prospective study. The original serum lipid values and an analysis of the normal erythrocyte sedimentation rates in various age groups have been published (Carlson and Lindstedt, 1968; Böttinger and Svedberg, 1967). Patients attending the health centre were engaged in active work and were subjectively healthy. All had a complete physical examination and routine tests were performed on blood and urine. Only those with entirely normal findir os were included in the study, and most were followed for several years, both before and after the study. The following criteria were used for the selection of subjects. Haemoglobin: men $12 \cdot 8-16 \cdot 8 \mathrm{~g} / 100 \mathrm{ml}$, women $11 \cdot 2-16.8 \mathrm{~g} / 100 \mathrm{ml}$; blood pressure (readings obtained at first visit without rest): systolic $<170 \mathrm{~mm} \mathrm{Hg}$, diastolic $<100 \mathrm{~mm}$ $\mathrm{Hg}$; urine, no sugar or glucose present.

All patients attending the health centre during one year formed the original study group, about 6,500 persons. Selection according to the criteria mentioned above was by data processing. There remained 2,458 persons $(1,447$ men and 1,011 women) who fulfilled these criteria. As the same group had been used for the study of variations in erythrocyte sedimentation rate with age, subjects with high values were not excluded. As was reported in the previous study (Böttiger and Svedberg, 1967) only 42 persons $(1.7 \%)$ had a rate of $25 \mathrm{~mm}$ in one hour or more.

Haemoglobin was determined as oxyhaemoglobin.

Serum lipid analyses were performed on blood drawn by venipuncture on the morning after overnight fasting. The blood was allowed to clot at room temperature and serum separated by centrifugation. Cholesterol was determined with the Tschugaeff reaction and triglycerides according to Carlson and Lindstedt, (1968).

Statistical analyses were performed using methods described by Snedecor (1956).

\section{Results}

From 20 years of age and upwards the serum lipid concentration increased with age in the case of men until 50 and in the case of women to about 60 . The haemoglobin values remained fairly constant with age in both men and women (Tables I and II).

TABLE I-Concentration of Haemoglobin, Plasma Cholesterol, and Triglycerides in Men in relation to Age. Mean Value \pm S.E. of Mean

\begin{tabular}{|c|c|c|c|c|}
\hline $\begin{array}{c}\text { Age } \\
\text { Years }\end{array}$ & $\begin{array}{c}\text { No. of } \\
\text { Subjects }\end{array}$ & $\begin{array}{l}\text { Haemoglobin } \\
(\mathrm{g} / 100 \mathrm{ml})\end{array}$ & $\begin{array}{c}\text { Plasma Cholesterol } \\
(\mathrm{mg} / 100 \mathrm{ml})\end{array}$ & $\begin{array}{c}\text { Triglycerides } \\
(\mathrm{mmol} / \mathrm{l} .)\end{array}$ \\
\hline $\begin{array}{l}20-24 \\
25-29 \\
30-34 \\
35-39 \\
40-44 \\
45-49 \\
50-54 \\
55-59 \\
60-64 \\
65-69\end{array}$ & $\begin{array}{r}15 \\
34 \\
75 \\
189 \\
320 \\
307 \\
250 \\
154 \\
73 \\
30\end{array}$ & $\begin{array}{l}14.6 \pm 0.20 \\
14.6 \pm 0.14 \\
14.6 \pm 0.09 \\
14.5 \pm 0.06 \\
14.5 \pm 0.04 \\
14.4 \pm 0.04 \\
14.4 \pm 0.05 \\
14.5 \pm 0.57 \\
14.4 \pm 0.11 \\
14.0 \pm 0.15\end{array}$ & 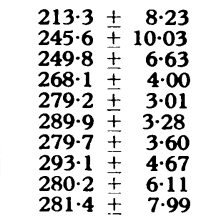 & $\begin{array}{l}1.15 \pm 0.16 \\
1.38 \pm 0.10 \\
1.37 \pm 0.06 \\
1.44 \pm 0.05 \\
1.61 \pm 0.05 \\
1.60 \pm 0.05 \\
1.54 \pm 0.05 \\
1.55 \pm 0.05 \\
1.37 \pm 0.05 \\
1.36 \pm 0.09\end{array}$ \\
\hline
\end{tabular}

TABLE II-Concentration of Haemoglobin, Plasma Cholesterol, and Triglycerides in Women in relation to Age. Mean Value $+S . E$. of Mean

\begin{tabular}{|c|c|c|c|c|}
\hline $\begin{array}{c}\text { Age } \\
\text { (Years) }\end{array}$ & $\begin{array}{l}\text { No. of } \\
\text { Subjects }\end{array}$ & $\begin{array}{l}\text { Haemoglobin } \\
\quad(\mathrm{g} / 100 \mathrm{ml})\end{array}$ & $\begin{array}{l}\text { Plasma Cholesterol } \\
(\mathrm{mg} / 100 \mathrm{ml})\end{array}$ & $\begin{array}{c}\text { Triglycerides } \\
(\mathrm{mmol} / \mathrm{l})\end{array}$ \\
\hline $\begin{array}{l}20-24 \\
25-29 \\
30-34 \\
35-39 \\
40-44 \\
45-49 \\
50-54 \\
55-59 \\
60-64 \\
65-69\end{array}$ & $\begin{array}{r}40 \\
38 \\
32 \\
114 \\
283 \\
226 \\
162 \\
85 \\
24 \\
7\end{array}$ & $\begin{array}{l}12.8 \pm 0.12 \\
12.7 \pm 0.12 \\
12.7 \pm 0.12 \\
12.7 \pm 0.07 \\
12.7 \pm 0.05 \\
12.6 \pm 0.05 \\
12.8 \pm 0.07 \\
12.8 \pm 0.09 \\
12.7 \pm 0.14 \\
12.9 \pm 0.32\end{array}$ & 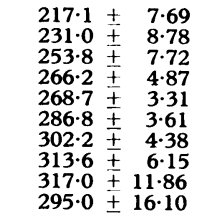 & $\begin{array}{l}0.96 \pm 0.04 \\
0.99 \pm 0.05 \\
1.09 \pm 0.10 \\
1.15 \pm 0.06 \\
1.08 \pm 0.03 \\
1.25 \pm 0.04 \\
1.29 \pm 0.03 \\
1.31 \pm 0.07 \\
1.18 \pm 0.08 \\
1.39 \pm 0.19\end{array}$ \\
\hline
\end{tabular}

Linear regression and correlation analyses between haemoglobin and lipid values were performed. The results are given in Table III for all subjects (aged 20-69) as well as for the group aged 20-54, where haemoglobin does not change with age and the lipids increase linearly with age. For the age group 20-54 there was a small but significant positive correlation between haemoglobin values and the two plasma lipid fractions for both men and women. When all subjects were included the correlations were still significant for haemoglobin and triglycerides in men, and for haemoglobin and cholesterol in women. The calculation of partial correlation coefficients, keeping age constant, did not significantly change the magnitude of the correlation between plasma lipid and haemoglobin values. Thus serum lipids-that is, cholesterol and triglycerides-increase with rising haemoglobin levels in both men and women even when the variations are withon the normal haemoglobin range.

\section{Discussion}

As stated above, earlier investigators found an association between low haemoglobin levels and low cholesterol values in anaemic women. Hashmi et al. (1969) studied severely anaemic (haemoglobin $4 \mathrm{~g} / 100 \mathrm{ml}$ ) patients in Karachi and found wide differences in lipid values (cholesterol, triglycerides, and phospholipids) in men as well as in women. We (Böttiger and Carlson, 1972) and others (Dawber and Kannel, 1961; L. Werkö, personal communication, 1971) have found that a high haemoglobin level in men is to be regarded as a "risk factor" for the development of myocardial infarction. The rate of myocardial infarctions in previously healthy men was significantly higher in those in the highest quintile-that is, those with the highest $20 \%$ of haemoglobin values-than in the rest of the subjects under study. Our study of myocardial infarctions was performed on the same subjects as those included here. Thus the possible correlation between haemoglobin and serum lipid values may have implications also for the development of coronary heart disease, emphasized by Rifkind and Gale (1967) and Elwood et al. (1970), and our findings are of wider interest than if they stood alone.

A correlation between haemoglobin levels and serum cholesterol and phospholipid values in anaemic women was found by Rifkind and Gale (1967) and in a larger series by Elwood et al. (1970). In both these studies, however, the differences in cholesterol values were apparent only when anaemic subjects

TABLE III-Linear Regression Analysis and Correlation $\left(r_{x y}\right)$ and Partial Correlation Coefficients ( $r_{\mathrm{p}}-$ Age Constant) Between Haemoglobin Values (y) and serum Lipid Levels $(x)$ in Men and Women

\begin{tabular}{|c|c|c|c|c|c|}
\hline Age & No. of Subjects & Variables & Regression Equation & rxy & $\mathbf{r}_{\mathbf{p}}$ \\
\hline \multicolumn{6}{|c|}{ Men } \\
\hline $20-69$ & 1,447 & \multirow{3}{*}{$\begin{array}{l}\text { Haemoglobin-triglycerides } \\
\text { Haemoglobin-cholesterol } \\
\text { Haemoglobin-triglycerides } \\
\text { Haemoglobin-cholesterol }\end{array}$} & $y=0.091 x+0.209$ & \multirow{3}{*}{$\begin{array}{l}0.101(\mathrm{P}<0.001) \\
0.040 \text { N.S. } \\
0.118(\mathrm{P}<0.01) \\
0.062(\mathrm{P}<0.05)\end{array}$} & \multirow{3}{*}{$\begin{array}{l}0.104(P<0.01) \\
0.056(P<. S . \\
0.125(P<0.01 \\
0.081(P<0.01)\end{array}$} \\
\hline $20-54$ & 1,190 & & $\begin{array}{l}y=2 \cdot 50 x+242 \cdot 6 \\
y=0 \cdot 124 x-0 \cdot 262 \\
y+4 \cdot 75 x+208 \cdot 0\end{array}$ & & \\
\hline & & & Women & & \\
\hline $20-69$ & 1,011 & \multirow{2}{*}{$\begin{array}{l}\text { Haemoglobin-triglycerides } \\
\text { Haemoglobin-cholesterol } \\
\text { Haemoglobin-triglycerides } \\
\text { Haemoglobin-cholesterol }\end{array}$} & $y=0.038 x+0.698$ & \multirow{2}{*}{$\begin{array}{l}0.060 \quad \text { N.S. } \\
0.089(\mathrm{P}<0.01) \\
0.070(\mathrm{P}<0.05) \\
0.082(\mathrm{P}<0.01)\end{array}$} & \multirow{2}{*}{$\begin{array}{l}0.054(\mathrm{~N} . \mathrm{S} . \\
0.079(\mathrm{P}<0.05) \\
0.068(\mathrm{P}<0.05) \\
0.081(\mathrm{P}<0.01)\end{array}$} \\
\hline $20-54$ & 895 & & $\begin{array}{l}y=7.06 x+189.4 \\
y=0.044 x+0.605 \\
y=6.00 x+198.5\end{array}$ & & \\
\hline
\end{tabular}


were included in the analysis. Elwood et al. found that women with a haemoglobin below $10.5 \mathrm{~g} / 100 \mathrm{ml}$ had a cholesterol value that on the average was $30 \mathrm{mg} / 100 \mathrm{ml}$ lower than in women with normal haemoglobin values. By using the regression equation in Table III for women aged 20-54 it can be calculated that a lowering of the haemoglobin from a normal of $14 \mathrm{~g} / 100 \mathrm{ml}$ to a low normal of $11 \mathrm{~g}$ would mean a decrease in the cholesterol value of $18 \mathrm{mg} / 100 \mathrm{ml}$, a figure of the same order of magnitude as that of Elwood et al. The same correlation was found for serum triglyceride values. The relation was also found in men both for cholesterol and for triglyceride, a finding not previously reported.

The variations in serum lipid values with the haemoglobin levels previously seen in anaemia have not been explained. They may, of course, be coincidental and largely independent of each other. As pointed out by Elwood et al., 1970, possibly the lower haemoglobin levels in women might be connected with lower serum lipid values, and this could partly explain the lower incidence of ischaemic heart disease in premenopausal women and of people in developing countries.

Possibly part of the relation between cholesterol and haemoglobin values in women, now extended to include also triglycerides, and men may be explained by changes in plasma volume. If we assume that the blood volume remains unchanged as the haemoglobin in women decreases from $14 \mathrm{~g}$ to $11 \mathrm{~g} / 100$ $\mathrm{ml}$, as quoted above, the packed cell volume would decrease from 40 to $32 \%$ and thus the plasma volume would increase from 60 to $68 \%$. If in women the total plasma pool of cholesterol and triglycerides were unchanged and the concentration of cholesterol was $250 \mathrm{mg} / 100 \mathrm{ml}$ and triglycerides of $1.10 \mathrm{mmol} / 1$. with a packed cell volume of $40 \%$, the values would decrease to $220 \mathrm{mg} / 100 \mathrm{ml}$ and $0.97 \mathrm{mmol} / 1$. if the packed cell volume went down to $32 \%$. Thus a change in plasma volume could be predicted to lower serum cholesterol and triglyceride values by
$30 \mathrm{mg} / 100 \mathrm{ml}$ and $0.13 \mathrm{mmol} / \mathrm{l}$. respectively. From the equations in Table III the corresponding figures can be calculated to be $18 \mathrm{mg} / 100 \mathrm{ml}$ for cholesterol and $0.13 \mathrm{mmol} / \mathrm{l}$. for triglycerides.

Assuming unchanged total plasma pools corresponding figures for men would be by calculation $30 \mathrm{mg} / 100 \mathrm{ml}$ and $0.19 \mathrm{mmol} / 1$. and by the regression equation (Table III) $14 \mathrm{mg} / 100 \mathrm{ml}$ and $0.37 \mathrm{mmol} / \mathrm{l}$. Though many assumptions are involved and there are great standard errors in the equations the values obtained by calculation, assuming unchanged plasma pools, are much the same as those obtained by applying the regression equation. Hence simple changes in plasma volume may in part account for the positive correlation between haemoglobin and plasma lipids. This new hypothesis is further substantiated by the findings of Rifkind and Gale (1967), who showed that the decrease in serum cholesterol and phospholipids was not due to a specific lowering of any one of the serum lipoprotein families but was caused by a proportionate fall in all three of the major lipoprotein families, a finding which is indeed compatible with a plasma volume dependent effect.

\section{References}

Böttiger, L.E., and Carlson, L.A. (1972) Skandia International Symphosia. In press.

Böttiger, L. E., and Svedberg, C. A. (1967). British Medical fournal, 2, 85. Carlson, L. A., and Lindstedt, S. (1968). Acta Medica Scandinavica, Suppl.,

Dawber, T. R., and Kannel, W. B. (1961). Modern Concepts of Cardiovascular Disease, 30, 671 .

Elwood, P. C., Mahler, R., Sweetnam, P., Moore, F., and Welsby, E. (1970). Lancet, 1, 589 .

Erben, F. (1902). Zeitschrift fur klinische Medizin, 47, 302.

Hashmi, J. A., et al. (1969). Fournal of the Pakistan Medical Association, 19, 131 .

Rifkind, B. M., and Gale, M. (1967). Lancet, 2, 640

Snedecor, G.W. (1956). Statistical Methods. Ames, Iowa, Iowa State College.

\title{
Serum Enzyme Levels in Diagnosis of Postoperative Myocardial Infarction
}

\author{
SYLVIA M. WATKINS, ADAM LEWIS
}

British Medical fournal, 1972, 3, 733-735

\section{Summary}

The levels of creatine kinase, hydroxybutyric dehydrogenase, and aspartate transaminase have been serially measured in the serum of patients undergoing surgery. Serum enzyme levels often rose to a range commonly found after myocardial infarction but fell to normal within 5-10 days. Raised serum enzyme levels have no diagnostic significance in a case of postoperative chest pain until after the fifth postoperative day, but may be significant thereafter.

\section{Introduction}

The differential diagnosis of chest pain in patients who have recently undergone chest or abdominal surgery is apt to be difficult; pain due to inflammatory lesions of the lungs or pleura, to surgical trauma, or to myocardial or pulmonary infarction may all produce similar symptoms. Raised levels of certain

Royal Free Hospital, London N.W.3

SYLVIA M. WATKINS, B.M., M.R.C.P., Senior Medical Registrar ADAM LEWIS, F.R.c.s., Senior Surgical Registrar serum enzymes occurs in some cases of pulmonary infarction (Henley, Schmidt, and Schmidt, 1966; Mullan, 1969) and in $90-97 \%$ of cases of myocardial infarction (Agress, 1959; Henley et al., 1966). These changes may precede any abnormality in the electrocardiogram by up to several days (Wood, 1968; Mullan, 1969), and serum enzyme estimations are therefore very valuable in the early diagnosis of myocardial infarction. Operative injury, however, may also result in the release of these same enzymes from the damaged tissues (especially skeletal muscle) into the circulation (Lawrence and Schulkins, 1956; Watanabe, Kaltus, and Semenson, 1957; Henley et al., 1966). Hence in the early postoperative period raised levels of serum enzymes are not necessarily significant in the diagnosis of myocardial infarction.

In order to establish the extent and duration of changes in serum enzyme levels due to operative injury the levels of aspartate transaminase, hydroxybutyric dehydrogenase, and creatine kinase were serially measured in the serum of patients undergoing a variety of surgical procedures.

\section{Patients and Methods}

Routine "cold" surgical patients undergoing thoracic or abdominal operations were studied. Aspartate transaminase, hydroxybutyric dehydrogenase, and creatine kinase were esti- 